Kwartalnik Młodych Muzykologów UJ

nr 39 (4/2018), s. 55-78

DOI 10.4467/23537094KMMUJ.18.039.9740

www.ejournals.eu/kmmuj

\title{
Zuzanna Daniec
}

UniWERSYTET JagiellońsKi W Krakowie

Akademia Muzyczna w Krakowie

\section{„Zmyślnie wykoncypowana, postmodernistyczna zabawka". Muzyka Pawła Mykietyna wobec kategorii postmodernizmu i konstruktywizmu na przykładzie III Symfonii na alt i orkiestrę ${ }^{1}$}

\section{Abstract}

"Cleverly Devised, Postmodern Toy": Paweł Mykietyn's Music in the Category of Postmodernism and Constructivism on the Example of III Symphony for Alto and Orchestra

Works of Paweł Mykietyn belong to the most characteristic trends of Polish contemporary music. His compositional attitude was individualised in the first decade of the 21st century, and today he is recognised as one of the most original Polish composers of the 20th and 21st centuries. Andrzej Chłopecki, when characterizing Mykietyn's music after the premiere of the composer's // Symphony, compared this work to a "cleverly devised, postmodern toy". Also Mykietyn's next, III Symphony (2011), can be considered in the context of the categories of postmodernism and constructivism. This work manifests the postmodern attitude, but it is also marked by strict, "cleverly devised", constructivist thinking. Its musical language

1 Tekst oparty na fragmentach pracy licencjackiej autorki pt. „III Symfonia” Pawła Mykietyna. Między postmodernizmem a konstruktywizmem, przygotowanej pod kierunkiem prof. dr hab. Teresy Maleckiej (Akademia Muzyczna w Krakowie, 2018). 
contains intertextual references to hip-hop and rap music; on the other hand, it includes such typical for Mykietyn measures as "(de)gradation form", "accelerando form", "permanent accelerando" and dodecaphony, which can be found while analysing the work. III Symphony can be also interpreted in relation to techniques of deconstruction, including both concept and structure of the composition.

\section{Keywords}

Paweł Mykietyn, postmodernism, constructivism, deconstruction, intertextuality

Paweł Mykietyn (ur. 1971) należy do najbardziej charakterystycznych polskich kompozytorów tzw. średniego pokolenia. Jego twórczość ma charakter wysoce indywidualny. Pozostając początkowo pod wpływem czołowych polskich twórców drugiej połowy XX wieku oraz przełomu wieków (Witolda Lutosławskiego, Henryka Mikołaja Góreckiego, Krzysztofa Pendereckiego, a przede wszystkim - Pawła Szymańskiego), w pierwszej dekadzie XXI wieku zindywidualizował on swoją postawę twórczą, stając się jednym z najbardziej oryginalnych kompozytorów współczesnych. Andrzej Chłopecki, charakteryzując jego twórczość tuż po prawykonaniu II Symfonii, porównał tę muzykę do „zmyślnie wykoncypowanej, postmodernistycznej zabawki”, frapującej „ludyczną uciechą erudycyjnych skojarzeń" oraz „inteligencją w konstruowaniu muzyki"2. Pod kątem tych dwóch kategorii: postmodernizmu, ujawniającego się poprzez mnogość stylistycznych odniesień i specyficzny dobór środków, a także konstruktywizmu wynikającego ze ścisłości muzycznej organizacji rozpatrywać można także następną, III Symfonię polskiego kompozytora.

Wiele utworów Mykietyna stanowi oryginalne zespolenie - jak określa sam kompozytor - spekulacji oraz intuicji, doprowadzających go do osiągnięcia podstawowego artystycznego celu: „stworzenia czegoś pięknego"3. Spekulacja, rozumiana jako etap prekompozycyjny, polega

2 A. Chłopecki, Mykietyna budowanie świata, „Gazeta Wyborcza” 5.07.2008, s. 26.

3 M. Herma, Algorytmy czuja bluesa, czyli przepis na przebój idealny, „Gazeta.pl Next” 2.04.2012, http://next.gazeta.pl/next/1,150857,11431816,Algorytmy_czuja_bluesa_ czyli_przepis_na_przeboj_idealny.html [dostęp: 2.12.2018]. 
w tym przypadku na myślowym konstruowaniu abstrakcyjnych, choć ściśle ustalonych zasad, organizujących wybrane parametry utworu. Dotyczą one najczęściej trzech muzycznych komponentów: formy, tempa i organizacji wysokości dźwiękowych. Poprzez intuicyjność, pojmowaną w kategoriach czysto muzycznej, kompozytorskiej inwencji, założone przez kompozytora reguły dopełnione zostają realną materią dźwiękową. Powstaje w efekcie muzyka ko munikatywna, choć wewnętrznie złożona. Sposób pracy nad swymi utworami tłumaczy Mykietyn w następujący sposób:

\section{[...] trzeba znaleźć rozsądne proporcje między matematyką a spontaniczno- ścią. [...] dla mnie ta faza spekulatywna daje możliwość zaskoczenia samego siebie. Tworzę jakieś prawo, potem przekładam je na muzykę i efekt, który powstaje, jest niemożliwy do osiągnięcia w inny sposób - ani poprzez impro- wizację, ani czystą intuicyjność 4 .}

Punktem wyjścia pracy kompozytorskiej Mykietyna jest „techniczny” aspekt utworu; kwestie estetyczne stają się wobec niego zjawiskiem wtórnym. Jak sam mówi:

\footnotetext{
Estetyczna warstwa moich kompozycji jest mniej istotna. Mnie jako kompozytora najbardziej interesują kwestie czysto techniczne, warsztatowe. [...] Oczywiście nie uważam, żeby pisanie muzyki wyłącznie spekulatywnej, pozbawionej warstwy intuicyjnej miało sens ${ }^{5}$.
}

Proces twórczy kompozytora określić można zatem jako dwuetapowy. W pierwszym etapie, należącym do fazy prekompozycji, tworzy on reguły, ustalając główne struktury swoich utworów. Na tej podstawie w drugim etapie - realizuje następnie materiał dźwiękowy.

Wspomniana komunikatywność muzyki Mykietyna łączy się w dużej mierze z jego artystyczną otwartością na style i konwencje - zarówno te nowsze, jak i nieco bardziej utrwalone tradycją. Jak sam twierdzi, jest „kompozytorem piszącym dosyć konwencjonalne dźwięki”'. Przystępna

4 A. Kwiecińska, W co gra Pawet Mykietyn?, „Ruch Muzyczny” 2007, nr 10, s. 6.

5 Taż, Koncert fortepianowy Pawła Mykietyna w świetle estetyki postmodernistycznej, praca magisterska, Instytut Muzykologii UW, Warszawa 2006, s. 106.

6 Polskie Wydawnictwo Muzyczne, Paweł Mykietyn „Herr Thaddäus”, reż. G. Kućmierz, 2018, https://web.facebook.com/PWMEdition/videos/1762997487097976/ [dostęp: 2.12.2018]. 
percepcyjnie brzmieniowość jego utworów wiąże się z rehabilitacją takich elementów, jak melodyka, rytm czy tonalność. Zarówno pod względem używanych środków kompozytorskich, jak i postawy, jego twórczość odpowiada tym samym częściom założeń muzycznego postmodernizmu.

\section{Postmodernizm}

W polskiej muzykologii twórczość Mykietyna interpretowana była dotychczas m.in. pod kątem takich nurtów współczesnej humanistyki, jak postmodernizm i dekonstrukcja ${ }^{7}$. Pomimo iż jego „branie tradycji w nawias"8 reprezentuje postawę typową dla estetyki postmodernizmu, sam kompozytor nie przykłada szczególnej wagi do tego typu kategoryzacji. Ceniąc zdobycze zarówno modernizmu (jako postawy zakładającej - jak mówi - „tworzenie muzyki od zera”), jak i postmodernizmu („korzystającego z tego, co jest własnością poprzednich pokoleń") ${ }^{9}$, w kompozytorskiej autorefleksji nie zwraca się ku tego rodzaju podziałom ${ }^{10}$.

Przynależność Mykietyna do muzycznego postmodernizmu określić można m.in. w kontekście klasyfikacji Krzysztofa Szwajgiera ${ }^{11}$. W swoim artykule pt. Transawangarda dzieli on postmodernizm na trzy „ponowoczesne" nurty: minimalizm, postmodernę i transawangardę. Drugi z nich - postmoderna - oparty na obecności tzw. podwójnego kodowania, rozumianego jako „współobecność w [jednym] utworze kodu nowoczesności i tradycji”"12, łączy się według autora z takimi pojęciami, jak tradycjonalizm, polistylistyka, dekonstrukcja czy intertekstualność ${ }^{13}$. Chcąc zatem dokładniej umiejscowić twórczość Mykietyna i jego III Symfonię w zróżnicowanej i szeroko rozumianej kulturze postmodernizmu, uznać można postmodernę - „połowicznie tylko przeciwstawiającą się nowoczesności" ${ }^{14}$ - za nurt temu kompozytorowi najbliższy.

7 B. Fiugajska, Technika dekonstrukcji w twórczości Pawła Mykietyna, Kraków 2012; A. Kwiecińska, Koncert fortepianowy..., dz. cyt.

8 M. Majchrowski, Mykietyna gra z czasem, „Tygodnik Powszechny” 2017, nr 27, https:// www.tygodnikpowszechny.pl/mykietyna-gra-z-czasem-148857 [dostęp: 2.12.2018].

9 A. Kwiecińska, Koncert fortepianowy..., dz. cyt., s. 106.

10 Tamże, s. 105.

11 K. Szwajgier, Transawangarda, [w:] Książka programowa 58. Międzynarodowego Festiwalu Muzyki Współczesnej „Warszawska Jesieñ”, Warszawa 2015, s. 1.

12 Tamże, s. 3-4.

13 Tamże.

14 Tamże. 


\section{Konstruktywizm}

Konstruktywizm, rozumiany jako ścisły sposób myślenia kompozytorskiego, zakłada obecność w dziele wszelkich „technicznych” rygorów ograniczających pierwiastek przypadkowości. Przyjmując taką definicję, kategorię tę uznać można za emblematyczną dla Mykietyna, choć w kontekście polskiej muzyki współczesnej - nie tylko jemu właściwą. Charakteryzując niegdyś twórczość Henryka Mikołaja Góreckiego, Krzysztof Droba wyróżnił „dominację czynnika konstruktywicznego” jako jeden z podstawowych elementów konstytuujących jego muzykę ${ }^{15}$. Ze względu na tę właśnie analogię w warsztacie kompozytorskim obu polskich twórców, podpartą wypowiedziami Mykietyna (wielokrotnie potwierdzającego własne inspiracje muzyką Góreckiego), konstruktywizm uznać można za kategorię łączącą ich postawy. Cytowaną już wcześniej wypowiedź na temat fazy spekulatywnej, przekładanej następnie na muzykę, zestawić można z charakterystyką Góreckiego sformułowaną niegdyś przez Adriana Thomasa i przedstawiającą proces pracy kompozytorskiej twórcy Symfonii pieśni żałosnych: „Postępował [on] w sposób niezwykle metodyczny: najpierw starannie i logicznie wypracowywał rozmaite cechy i parametry, dopiero potem przystępował do właściwej kompozycji”16.

Mimo iż jako kompozytor Mykietyn skupia się przede wszystkich na technicznym oraz warsztatowym aspekcie swoich utworów ${ }^{17}$, na temat ten wypowiada się zazwyczaj dość lakonicznie, starając się nie ujawniać,,wewnętrznych” aspektów swojej pracy twórczej. Podobnie jak niegdyś Górecki, także i młodszy z kompozytorów nie ujawnia zbyt często technicznych szczegółów swoich kompozycji. Jak sam mówi:

\footnotetext{
Ostatecznym celem jest [dla mnie] piękno i przekaz - żeby muzyka wywarła jakiś efekt na słuchaczu, jakiś rodzaj emocji, wrażenie intelektualne. [...] cała sprawa techniczna jest w pewnym sensie nieistotna [...], pozostaje to moją prywatną sprawą ${ }^{18}$.
}

15 K. Droba, Górecki Henryk Mikołaj, [w:] Encyklopedia muzyczna PWM. Część biograficzna, red. E. Dziębowska, t. 3 (EFG), Kraków 1987, s. 424. Zob. także: M. Jabłoński, Encyklopedia muzyczna PWM. Górecki, Kraków 2011.

16 A. Thomas, Energia - ruch - zycie. Geneza „Elementi”, „Scontri” 2013, nr 1, s. 13.

17 A. Kwiecińska, Koncert fortepianowy..., dz. cyt., s. 106.

18 P. Mykietyn, Paweł Mykietyn. Wywiad, rozmowę przepr. E. Szczecińska i J. Topolski, „Glissando” 2010, nr 16, http://glissando.pl/tekst/wywiad-pawel-mykietyn-2/ [dostęp: 2.12.2018]. 
Porównując konstruktywizm Góreckiego do konstruktywistycznych cech muzyki Mykietyna, zastanowić można się nad sposobem tego typu myślenia w utworach młodszego kompozytora. Konstruktywizm Mykietyna zdaje się bazować na niezmiennej, obranej przez niego linii rozwojowej: opiera on swoje utwory na stałych i abstrakcyjnych regułach, obejmujących szereg różnorodnych metod ścisłości i rygorów, współegzystujących często także w ramach jednego utworu bądź wybranych jego fragmentów. Co ważne, stosowane przez Mykietyna techniki konstruktywistyczne wiążą się bardziej z ogólną ścisłością strukturalną, aniżeli dokładną realizacją danego rygoru, co widoczne jest zwłaszcza w dojrzałych utworach polskiego kompozytora - między innymi w III Symfonii.

\section{„Czas jest podstawowym zagadnieniem w muzyce" 19}

Jak wcześniej wspomniano, konstruktywizm utworów Mykietyna skupia się wokół trzech podstawowych parametrów: formy, tempa oraz organizacji wysokości dźwiękowych (powiązanej często z dwunastotonowością). W znacznej części utworów Mykietyna makro- oraz mikroforma kształtowana jest na zasadzie redukcjonizmu, polegającego na stopniowym skracaniu części cyklu bądź szeregowanych odcinków wewnątrz kompozycji, a także na celowym skracaniu odległości pomiędzy wartościami rytmicznymi na obszarze wybranych fragmentów utworu. Środki te, wyrażające upodobanie Mykietyna do „operacji z czasem"20, określono w literaturze mianem tzw. formy acceleranda oraz techniki tzw. permanentnego acceleranda (pierwszy z tych terminów został wprowadzony przez Beatę Fiugajskąą); odnoszą się one do „temporalnego nurtu”22 twórczości Mykietyna.

Istotą formy acceleranda jest stopniowy redukcjonizm naprzemiennych, skontrastowanych odcinków muzycznych, połączony z coraz szybszym ich następstwem w ramach całego utworu bądź jego wybranych fragmentów; taki sposób skumulowania materiału dźwiękowego doprowadza do częściowo „agogicznego” pojmowania muzycznej

19 Tamże.

20 Polskie Wydawnictwo Muzyczne, Paweł Mykietyn „Herr Thaddäus”, dz. cyt.

21 B. Fiugajska, dz. cyt., s. 37.

22 M. Majchrowski, dz. cyt. 
formy kompozycji. Tzw. permanentne accelerando polega $\mathrm{z}$ kolei na równomiernym przyspieszaniu realnego tempa metronomicznego w utworze ${ }^{23}$. Technikę tę wyjaśnia kompozytor następująco:

\section{[...] tempo nie jest stałą prostą, lecz krzywą, i cały czas maleje lub wzrasta, i to na odcinku paru minut. W momencie, kiedy tempo staje się dwukrotnie szybsze niż wejściowe, to dyrygent zaczyna pokazywać jego połowę, ale ono ciągle rośnie ${ }^{24}$.}

Jak mówi sam Mykietyn, po owe „operacje z czasem” sięgnął po raz pierwszy w 2000 roku i nadal stara się ten kierunek eksplorować 25 . Plastyczne kształtowanie agogicznej warstwy utworów, oddziałujące na percepcyjną sferę jego odbioru, powiązane jest ściśle z dramaturgicznym sposobem pojmowania dzieła. Zauważa to zresztą sam kompozytor: „Zawsze porównuję pisanie muzyki do tworzenia dobrego dramatu [...], myślę takimi kategoriami jak wątki, wydarzenia - tylko że wypowiadam się za pomocą dźwięków" ${ }^{26}$.

\section{Symfonia. Analiza}

Mówię lekkim językiem, ale to nie jest błahostka ${ }^{27}$.

III Symfonia na alt i orkiestrę skomponowana została w roku 2011 na zamówienie Narodowego Instytutu Audiowizualnego, w związku z obchodami objęcia przez Polskę prezydencji w Unii Europejskiej. Jest to, paradoksalnie, drugi utwór symfoniczny Mykietyna; swą właściwą pierwszą symfonię (2007) zatytułował on bowiem jako Drugq̨ ${ }^{28}$. Jako

23 Tamże.

24 Tamże.

25 Polskie Wydawnictwo Muzyczne, Paweł Mykietyn „Herr Thaddäus”, dz. cyt.

26 P. Mykietyn, Komponuję autobiografię, rozmowę przepr. A. Grużewska, „Polityka” 2000, nr 7, https://archiwum.polityka.pl/art/komponuje-autobiografie, 363175.html [dostęp: 2.12.2018].

27 P. Mykietyn, Paweł Mykietyn. Prezydencja w rytmie triphopu, rozmowę przepr. F. Łobodziński, „Newsweek” 27.06.2011, https://www.newsweek.pl/pawel-mykietyn-prezydencja-w-rytmie-trip-hopu/3j8cqtw [dostęp: 2.12.2018].

28 P. Mykietyn, Wywiad o „III Symfonii” Pawła Mykietyna[video], rozmowę przepr. K. Naliwajek-Mazurek, „Ninateka”, http://ninateka.pl/film/wywiad-o-iii-symfonii-pawla-mykietyna-pawel-mykietyn [dostęp: 2.12.2018]. 
kompozycja realizująca zewnętrzne, gatunkowe założenia sygnalizowane przez tytuł (w postaci obsady symfonicznej, monumentalizmu oraz cykliczności), III Symfonia ze względu na swój współczesny język muzyczny podziela los innych kompozycji dwudziesto- i dwudziestopierwszowiecznych, które - jak pisał niegdyś Carl Dahlhaus - „jedynie pod presją pozwalają się podporządkować jakiemuś gatunkowi"29. Jest to dzieło reprezentujące symfonikę współczesną, a dokładnie, według klasyfikacji Hermanna Danusera, „hybrydyczny”, postmodernistyczny typ tego gatunku ${ }^{30}$. Owa współczesność objawia się w utworze zarówno poprzez język muzyczny - wielostylistyczny, czerpiący z dawnych oraz nowych konwencji, technik i stylów - jak i poprzez warstwę tekstową, odzwierciedlającą obraz dwudziestopierwszowiecznej postkultury.

Dla genezy utworu istotna okazała się świadoma chęć nawiązania przez kompozytora do współczesnej muzyki rozrywkowej. Mykietyn stwierdza, iż ważne źródło inspiracji podczas pracy nad kompozycją stanowily dla niego nurty rapu, hip-hopu oraz trip-hopu ${ }^{31}$ :

\begin{abstract}
Nie dzielę muzyki na poważną i rozrywkową, to dość chybione terminy. Ale [tak] jak swego czasu przetwarzałem konwencje klasyczne czy barokowe - co wynikało z mojej ówczesnej fascynacji muzyką Pawła Szymańskiego - tak tutaj dokonuję podobnych zabiegów, ale na bazie muzyki młodzieżowej²
\end{abstract}

Pomimo owych wyraźnych inspiracji materiał dźwiękowy Symfonii nie opiera się wyłącznie na stylizacji muzyki wywodzącej się z kręgu kultury hip-hopu. Jest on bardzo heterogeniczny - zarówno pod względem języka muzycznego, jak i stylu. Podobnie jak w innych „dojrzałych" kompozycjach, także w III Symfonii powtórzył Mykietyn charakterystyczne dla siebie środki warsztatowe, przez co kompozycja ta stanowi rodzaj kumulacji i podsumowania dotychczasowych pomy-

29 C. Dahlhaus, Estetyka muzyki, tłum. Z. Skowron, Warszawa 2007, s. 17-18.

30 H. Danuser, Die Musik des 20. Jahrhunderts, Laaber 1984, s. 40o; cyt. za: T. Malecka, Kwartety smyczkowe Henryka Mikołaja Góreckiego wobec tradycji gatunku, „Teoria Muzyki. Studia, interpretacje, dokumentacje" 4 (2014), s. 53.

31 P. Mykietyn, Wywiad o „III Symfonii”..., dz. cyt.; P. Mykietyn, Paweł Mykietyn o swojej najnowszej symfonii [video], rozmowę przepr. M. Peryt, https://www. youtube.com/watch?v=3yiodowM-3I [dostęp: 2.12.2018].

32 T. Cyz, Uwaga na kulturę!: O „III Symfonii” Pawła Mykietyna, „Dwutygodnik” 2011, nr 6o, https://www.dwutygodnik.com/artykul/2375-uwaga-na-kulture-o-iii-symfonii-mykietyna.html [dostęp: 2.12.2018]. 
słów twórcy. Reprezentuje zatem zarówno „matematyczny” (oparty na określonych, prekompozycyjnych strukturach), dramaturgiczny, jak i postmodernistyczny sposób kształtowania dużej formy wokalno-instrumentalnej i jej języka dźwiękowego.

Pracę nad III Symfoniq rozpoczął Mykietyn od muzycznej warstwy utworu - wyboru tekstu dokonał natomiast nieco później. Zarówno muzyka, jak i tekst kompozycji odzwierciedlają główny obecnie wyznacznik stylu polskiego twórcy, jakim jest dążenie do pewnego rodzaju „odciążania” ${ }^{33}$. W III Symfonii wykorzystane zostały prywatne, istniejące już wcześniej teksty autorstwa Mateusza Kościukiewicza (ur. 1986). Jak mówi kompozytor, sam fakt ich wyboru był „dość przypadkowy"34; kierował się przy tym kryterium elastyczności warstwy słownej, umożliwiającej swobodne połączenie $\mathrm{z}$ warstwą muzyczną utworu. Według Mykietyna „wybitna” współczesna poezja, stanowiąca sama w sobie „dzieło zamknięte”, nie jest odpowiednia do wykorzystania w muzycznym utworze ${ }^{35}$. W ślad za tą właśnie myślą kompozytor wybrał teksty hermetyczne i nieco abstrakcyjne, pozbawione ścisłej fabuły, wszelkiego patosu i - jak mówi sam twórca - „ciężarów”, które „są czasami może niekonieczne” 36 . Teksty te - pisane pierwotnie w formie wiadomości SMS-owych - czerpią z języka potocznego i młodzieżowego. Niekonwencjonalny tok narracji, nakierowując jedynie na określony kontekst sytuacyjny, odzwierciedla charakter świata przedstawionego: ulicznego zgiełku oraz „miejskiej dżungli” ${ }^{37}$.

III Symfonia jest cyklem pięcioczęściowym. Pod względem rozmiarów jej wewnętrzna struktura ma charakter redukcyjny - każda kolejna część utworu jest krótsza od poprzedniej. Heterogeniczność materiału muzycznego opiera się na odpowiednio skonstruowanym następstwie odcinków muzycznych, odwołujących się bezpośrednio oraz pośrednio do różnorodnych stylów, konwencji i technik - zarówno tych wywodzących się z europejskiej muzyki „poważnej”, jak i tych związanych ze współczesną muzyką rozrywkową. Odcinki te oraz niektóre pojedyncze formuły brzmieniowe powtarzane i przeplatane są ze

33 P. Mykietyn, Wywiad o „III Symfonii”..., dz. cyt.

34 Tamże.

35 Tamże.

36 Tamże; P. Mykietyn, Uwaga na kulturę!: „III Symfonia” Mykietyna, rozmowę przepr. T. Cyz, „Dwutygodnik” 2011, nr 59, https://www.dwutygodnik.com/artykul/2335-uwaga-na-kulture-iii-symfonia-mykietyna.html [dostęp: 2.12.2018].

37 Tamże. 
sobą w ramach kolejnych pięciu części utworu. Sposób kształtowania formy, polegający na naprzemiennym przywoływaniu fragmentów muzycznych o niemal surkonwencjonalnym charakterze, zauważalny był już we wcześniejszych utworach Mykietyna. Analizując Pasje według św. Marka, Krzysztof Cyran w odniesieniu do takich właśnie zestawionych ze sobą fragmentów zaproponował określenie „muzyki”, wywiedzione z koncepcji muzycznej intertekstualności Mieczysława Tomaszewskiego ${ }^{38}$. Zdefiniował je jako odmienne „typy ukształtowań materiału dźwiękowego, [odwołujące się] do obszarów stylistycznych i idiomów muzycznych różnych epok”, różniące się między sobą „,specyficznym współdziałaniem elementów i odpowiednimi środkami wykonawczymi" 39 . W przypadku III Symfonii odwołania te dotyczą z jednej strony idiomów charakterystycznych dla współczesnej muzyki rozrywkowej (rapu, hip-hopu oraz trip-hopu), z drugiej - cech odnoszących się do tradycji muzyki „poważnej”. Naśladowanie elementów tych stylów determinuje melorytmikę, harmonikę oraz kształt brzmieniowy poszczególnych „muzyk”. Jako zamknięte całości odcinki te są zwarte oraz jednolite wewnętrznie, co sprzyja ich słuchowej rozpoznawalności i uwypukla szeregową, quasi-refreniczną budowę wybranych części utworu (każda $\mathrm{z}$ „muzyk” staje się bowiem swego rodzaju refrenem). Tabela 1 przedstawia zestawienie oraz podstawową charakterystykę owych „muzyk”, wyodrębionych na podstawie charakterystyki brzmieniowej.

Schemat następstw oraz powtarzalności wszystkich „muzyk” występujących w Symfonii, ujętych w szeregowane odcinki muzyczne, przedstawić można za pomocą grafiki odzwierciedlającej redukcyjny sposób ich formalnego rozmieszczenia wewnątrz utworu. Wszystkie „muzyki” wprowadzane są po raz pierwszy już w części I (il. 1) - najdłuższej, a zarazem syntetyzującej materiał muzyczny utworu, co podkreśla jej istotną rolę wobec całości cyklu ${ }^{40}$.

38 K. Cyran, „Kanon i postmodernizm” w twórczości religijnej kompozytorów polskich przełomu XX i XXI wieku, praca doktorska, Akademia Muzyczna w Krakowie, Kraków 2015, s. 276-277; M. Tomaszewski, Na otwarcie: dlaczego „muzyka w muzyce”, [w:] Muzyka w muzyce. Spotkania muzyczne w Baranowie, red. T. Malecka, L. Polony, Kraków 1980; przedruk w: tenże, O muzyce polskiej w perspektywie intertekstualnej. Studia i szkice, Kraków 2005.

39 K. Cyran, dz. cyt., s. 276-277.

40 P. Mykietyn, Wywiad o „III Symfonii”..., dz. cyt. 


\begin{tabular}{|c|c|c|c|c|c|}
\hline „Muzyka” & $\begin{array}{l}\text { Charakterystyka } \\
\text { materiału } \\
\text { dźwiękowego: } \\
\text { faktura, } \\
\text { współbrzmienia, } \\
\text { mikroforma }\end{array}$ & $\begin{array}{l}\text { Określenia } \\
\text { ekspresyjne } \\
\text { i wykonawcze }\end{array}$ & $\begin{array}{l}\text { Dominujące } \\
\text { instrumentarium } \\
\text { (uporządkowane } \\
\text { wg warstw } \\
\text { fakturalnych) }\end{array}$ & Metrorytmika & $\begin{array}{l}\text { Dominująca } \\
\text { dynamika }\end{array}$ \\
\hline A & $\begin{array}{l}\text { imitacja brzmienia } \\
\text { zestawu perkusyjnego: } \\
\text { repetowane } \\
\text { dwudźwięki (Vn I), } \\
\text { rytmiczny } \\
\text { akompaniament } \\
\text { orkiestry oraz } \\
\text { krótkie fragmenty } \\
\text { „przejściowe”; } \\
\text { homorytmia, } \\
\text { progresje }\end{array}$ & poco staccato & $\begin{array}{l}\text { Vn I, } \\
\text { Tn, Vc, Cb, } \\
\text { Cr, Tr, Vn II, VI }\end{array}$ & $\begin{array}{l}\text { 4/4; } \\
\text { pulsacyjność, } \\
\text { motoryczność } \\
\text { (Vn I divisi); } \\
\text { rytm } \\
\text { punktowany } \\
\text { (orkiestra) }\end{array}$ & $f$ \\
\hline B & $\begin{array}{l}\text { chorałowość, } \\
\text { homorytmia; frazowa } \\
\text { struktura; dodekafonia }\end{array}$ & cantabile & $\begin{array}{l}\mathrm{Fl}, \mathrm{Cl} \\
\text { (+ bongosy, } \\
\text { bęben, tom-tom) }\end{array}$ & $\begin{array}{l}\text { zmienne } \\
\text { metrum; } \\
\text { nieregularna } \\
\text { rytmika }\end{array}$ & $p p$ \\
\hline C & $\begin{array}{l}\text { odcinek sonorystyczny: } \\
\text { dysonansowe piony } \\
\text { orkiestrowe tremolo } \\
\text { oraz pojedyncze } \\
\text { "uderzenia" } \\
\text { instrumentów } \\
\text { blaszanych }\end{array}$ & - & $\begin{array}{l}\text { tutti } \\
\text { (archi divisi) }\end{array}$ & $\begin{array}{l}\text { zmienne } \\
\text { metrum; } \\
\text { nieregularna } \\
\text { rytmika }\end{array}$ & zmienna \\
\hline D & $\begin{array}{l}\text { imitacja rapu i quasi- } \\
\text {-tonalny } \\
\text { akompaniament } \\
\text { orkiestry }\end{array}$ & - & $\begin{array}{l}\text { Alt, } \\
\mathrm{Fl}, \mathrm{Cl}, \mathrm{Vn}, \mathrm{Vl}, \mathrm{Vc}, \\
\mathrm{Cb}, \\
\mathrm{Tr}, \mathrm{Vb}\end{array}$ & $\begin{array}{l}\text { ruch triolowy; } \\
\text { miarowość, } \\
\text { regularne } \\
\text { akcenty }\end{array}$ & $m f$ \\
\hline$E$ & $\begin{array}{l}\text { faktura } \\
\text { punktualistyczna; } \\
\text { kolorystyka, } \\
\text { niekonwencjnalne } \\
\text { efekty brzmieniowe }\end{array}$ & - & tutti & $\begin{array}{l}\text { nieregularna } \\
\text { rytmika, } \\
\text { dźwięki } \\
\text { izolowane } \\
\text { pauzami }\end{array}$ & zmienna \\
\hline
\end{tabular}

Tabela 1. Charakterystyka brzmieniowa "muzyk" III Symfonii. 


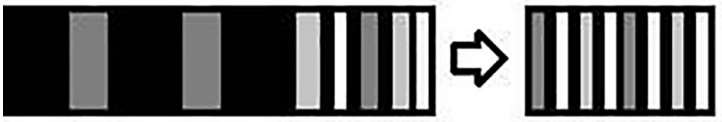

Ilustracja 1. Graficzne, przybliżone odzwierciedlenie początku i końca I części Symfonii. Ilustracja odzwierciedla "(de)gradacyjne" 41 ukształtowanie jej budowy, zgodne z zasadą formy acceleranda.

Jak już wspomniano, dyspozycję formalną „muzyk”, zarówno w sferze mikro-, jak i makroformy utworu, scharakteryzować można za pomocą terminu „forma (de)gradacji”, wprowadzonego przez Beatą Fiugajską w odniesieniu do wcześniejszych utworów Mykietyna ${ }^{42}$. Środek ten wiąże się ze wspomnianą wcześniej formą acceleranda i w swym ogólnym sensie polega na "nobilitacji cechy marginalnej i [jednoczesnej] degradacji cechy zasadniczej” ${ }^{43}$. W utworze objawia się on we wszelkich sytuacjach, w których wzajemny stosunek wybranych elementów muzycznej formy ulega przeciwproporcjonalnym przemianom. Owymi elementami w III Symfonii są przede wszystkim „muzyki”. Zmiana ich hierarchizacji zachodzi zarówno w ramach poszczególnych części utworu, jak i pomiędzy nimi. Muzyczne „powroty" odcinków muzycznych opierają się zatem na określonej zasadzie: fragmenty pełniące w I części rolę jedynie „drugoplanową”, w części II oraz III stają się podstawowym materiałem muzycznym. Zasada formalnej (de)gradacji odbywa się w analogiczny sposób na gruncie mikroformy, co widoczne jest zwłaszcza w budowie I części utworu: „muzyki” prezentowane początkowo często na dłuższych odcinkach („muzyka” A oraz B), w dalszym rozwoju tej części ustępują coraz szybszym następstwom „muzyk” pozostałych (C, D oraz E).

Nieco bliższa charakterystyka dwóch skontrastowanych odcinków otwierających I część utworu - „muzyki” A oraz B - pozwoli uwypuklić zróżnicowany i naznaczony surkonwencjonalizmem charakter materiału muzycznego III Symfonii:

- „Muzyka” A, zaprezentowana tuż po wstępie, opiera się na naśladownictwie brzmienia standardowego zestawu perkusyjnego, wykorzystywanego w muzyce rozrywkowej. Sam kompozytor porównuje pierwszy jej pokaz do „rytmu całego zestawu per-

41 B. Fiugajska, dz. cyt., s. 35 .

42 Tamże.

43 Tamże, s. 36. 


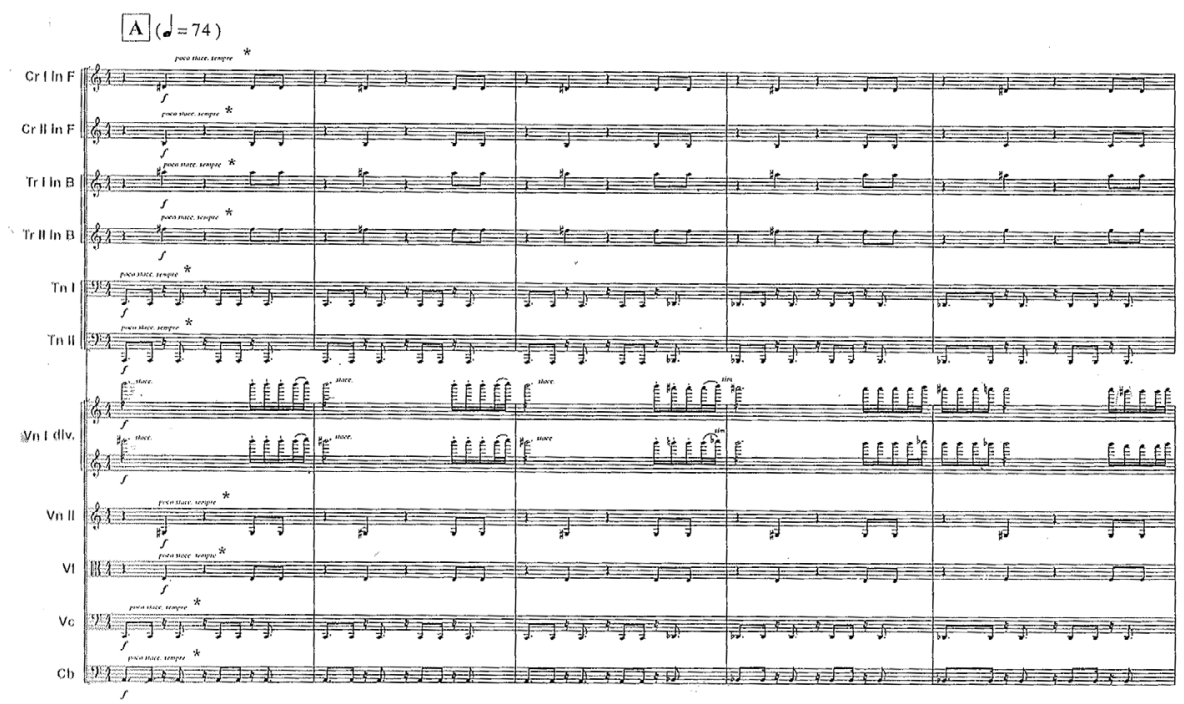

Przykład 1. P. Mykietyn, III Symfonia, cz. I, t. 19-23. Początek pierwszego pokazu „muzyki" A.

kusyjnego przetransportowanego na instrumenty symfoniczne”, określając go jako „formułę rytmiczną”, usytuowaną w kontekście melodycznym i harmonicznym ${ }^{44}$. Jak mówi, jest to „najprostszy rytm grany na tradycyjnej perkusji, ale bez perkusji" 45 . „Muzyka” A, realizowana przez instrumenty smyczkowe oraz dęte (drewniane i blaszane), opiera się na powtarzalnym schemacie rytmicznym o wyrazistej pulsacji. Podstawą jej współbrzmień są repetycyjne, urytmizowane wielodźwięki głosów orkiestry; towarzyszą im repetowane dwudźwięki (w stałej odległości trzech półtonów) dwojga Violini I divisi w wysokim rejestrze. W każdej z tych dwóch warstw następują częste, nieregularne przesunięcia o sekundę w górę lub w dół (przykład 1). Co paradoksalne, w celu imitacji odgłosów zestawu perkusyjnego, a więc brzmienia charakterystycznego dla współczesnej muzyki rozrywkowej, kompozytor posłużył się podstawowymi instrumentami tradycyjnej orkiestry symfonicznej (smyczkowymi oraz dętymi), pozbawiając tym samym „styl perkusyjny” jego naturalnego kontekstu brzmieniowego.

44 P. Mykietyn, Wywiad o „III Symfonii”..., dz. cyt.

45 Tenże, Uwaga na kulturę!..., dz. cyt. 

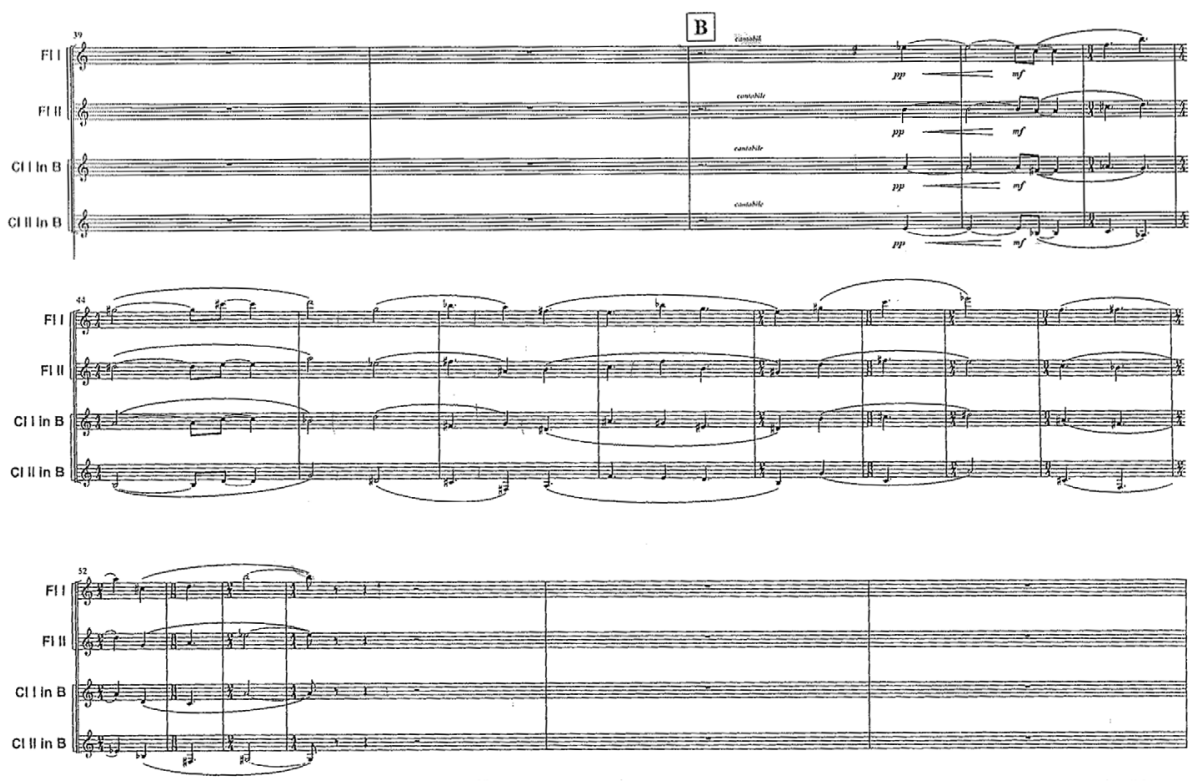

Przykład 2. P. Mykietyn, III Symfonia, cz. I, t. 41-57. Pierwszy pokaz „muzyki” B.

- Podstawę dźwiękową drugiej z „muzyk” (B) stanowią następstwa kantylenowych, nieregularnych fraz czterech instrumentów dętych. Poruszają się one homorytmicznie, choć ze zmienną akcentuacją. Struktura ich wysokości dźwiękowych jest oparta na ośmioczęściowej nadserii dodekafonicznej: dwadzieścia cztery czterodźwiękowe piony (t. 41-55) tworzą osiem kolejnych serii wertykalnych. Są one skonstruowane w taki sposób, iż każde trzy kolejne piony owych instrumentów wykorzystują pełną skalę dwunastotonową. Linie melodyczne skrajnych głosów zespołu (I flet oraz II klarnet), stanowiące wypadkową owych serii wertykalnych, tworzą przy tym cztery równoczesne serie linearne (przykład 2).

Dokładną strukturę wysokości dźwiękowych powyższego fragmentu ukazuje tabela 2. 


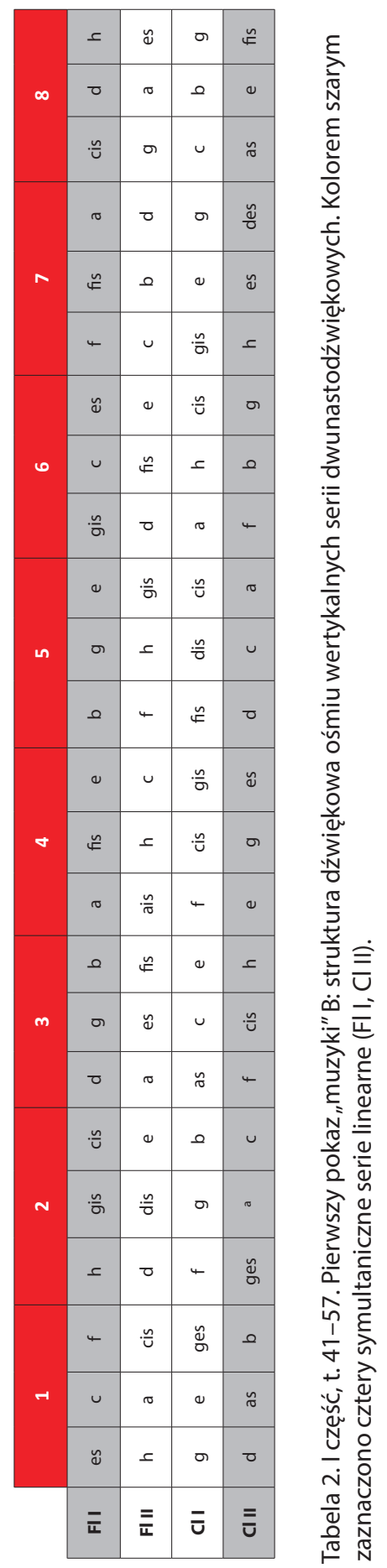

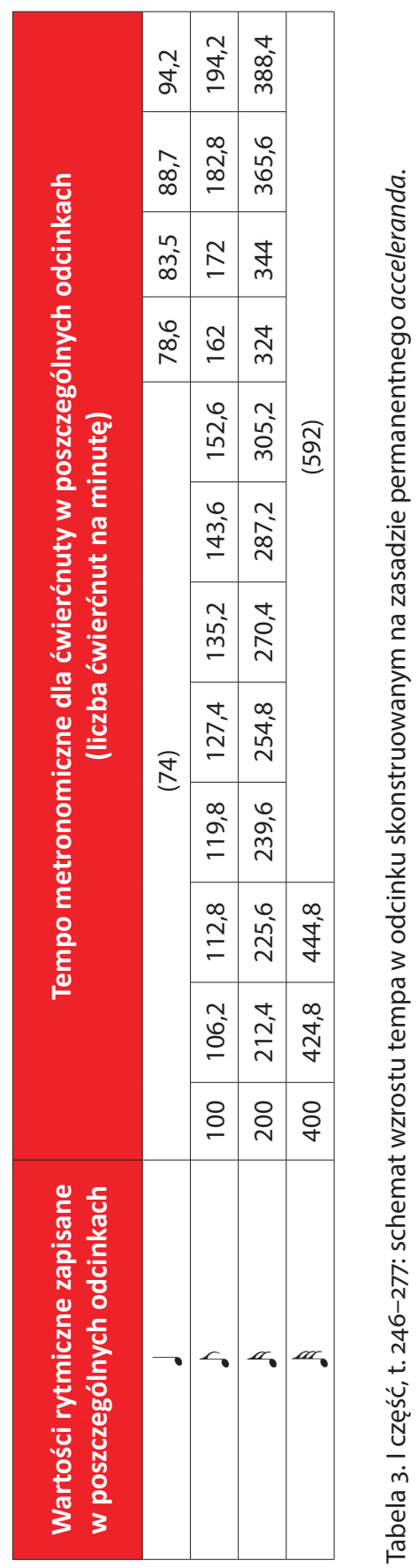


W finałowym, kulminacyjnym punkcie I części III Symfonii zastosowany został kolejny środek charakterystyczny dla techniki kompozytorskiej Mykietyna: permanentne accelerando. Jest to fragment, w którym orkiestrowe piony akordowe, prowadzone od początku homorytmicznie, wraz ze stałym wzrostem tempa ulegają stopniowemu uproszczeniu pod względem harmonicznym, aż do „czystego” współbrzmienia b-moll wieńczącego całą kulminację.

Stopniowemu, równomiernemu przyspieszeniu tempa w ramach tego odcinka towarzyszą w zapisie nutowym zmiany rytmiczne o charakterze dyminucji (przykład 3). Początkowo każdy takt obejmuje cztery ćwierćnuty, następnie osiem ósemek, szesnaście szesnastek itd. Przy każdej takiej zmianie liczbowa wartość tempa metronomicznego zmniejsza się o połowę; ułatwia to odczytanie tego odcinka wykonawcom. Dzięki

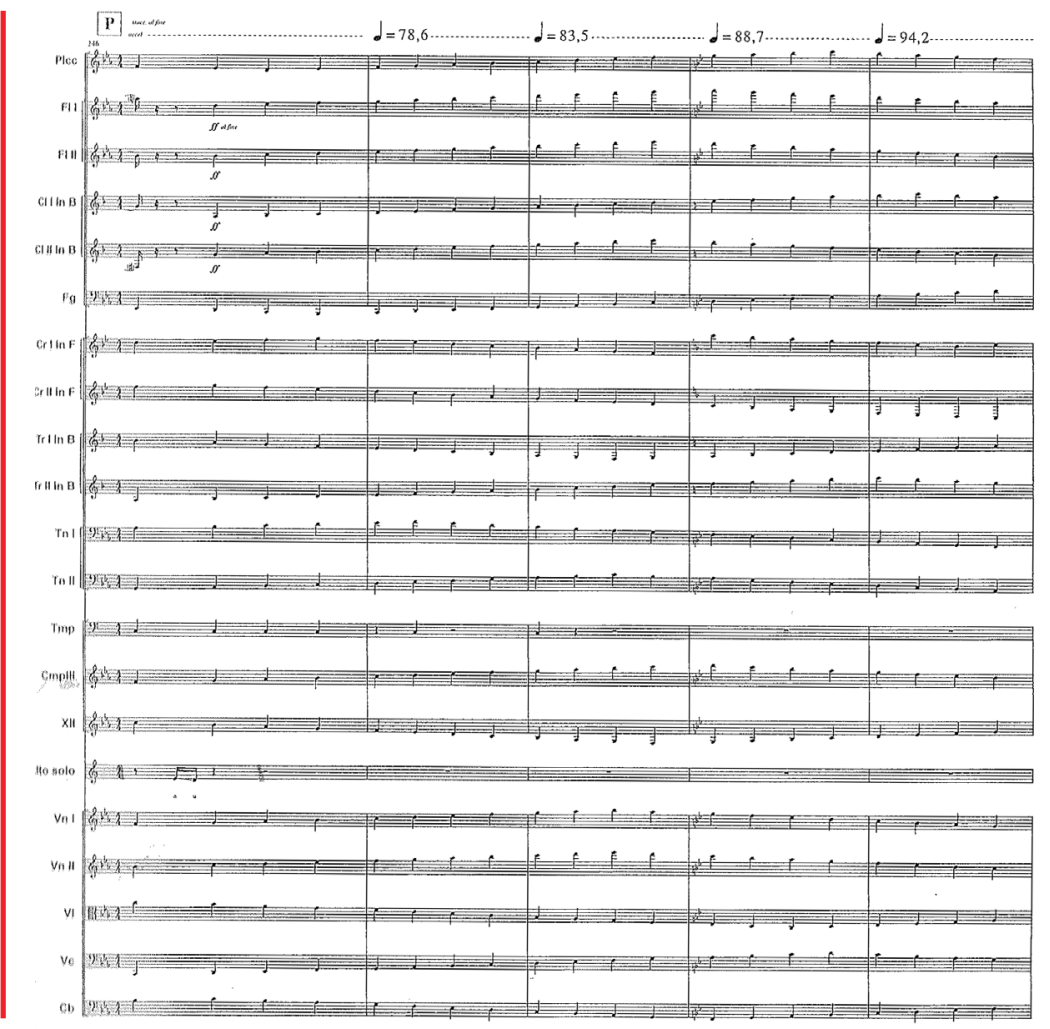




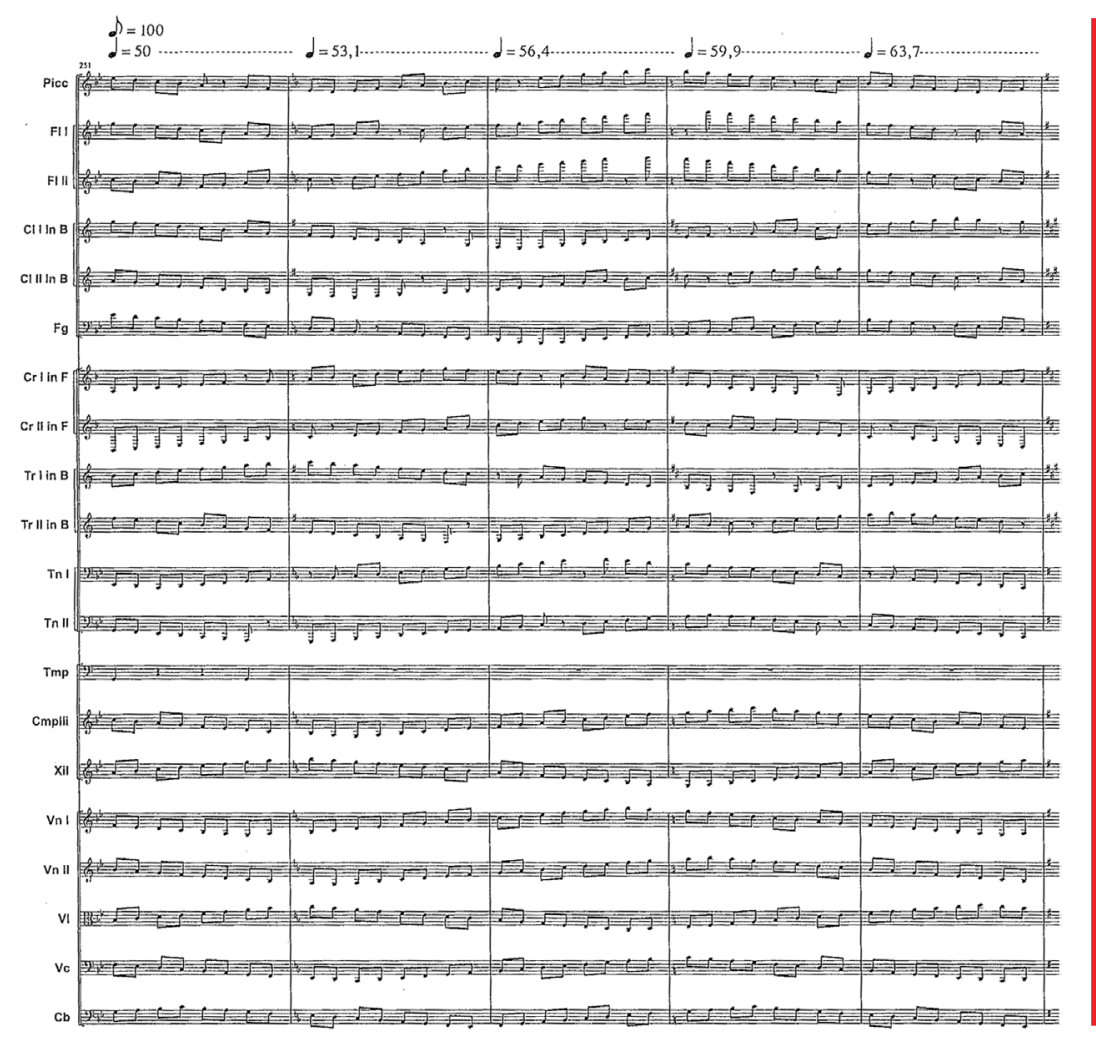

Przykład 3. P. Mykietyn, III Symfonia, cz. I, t. 246-255. Finał: początek permanentnego acceleranda.

wzrostowi tempa metronomicznego powstaje wrażenie ciągłego, niepohamowanego przyspieszania wartości rytmicznych, pozbawionych wyraźnych podziałów metryczno-akcentuacyjnych (tabela 3).

Taki wzrastający ciąg liczbowy oparty jest na zasadzie zbliżonej do matematycznego ciągu geometrycznego (sam Mykietyn uznaje permanentne accelerando właśnie za przykład „geometrycznego" myślenia kompozytorskiego ${ }^{46}$ ). Nie jest on jednak ścisły pod względem zasad matematycznych - kompozytor dostosował go bowiem w pewnym stopniu do wymogów praktycznych, zapisując kolejne wartości metronomiczne w sposób jedynie przybliżony, poprzez skrócenie do jednej cyfry po przecinku.

46 M. Herma, dz. cyt. 


\section{Symfonia. Interpretacja}

Poprzez nieuznawanie podziałów na tzw. muzykę poważną i rozrywkową Mykietyn wpisuje się w nurt myślowy związany z ideą różnorodności, pluralizmu i wychodzenia poza tradycyjne, wartościujące bariery w sztuce. Świadome i celowe łączenie stylu niskiego z wysokim - popularnego z koncertowym - wskazuje na obecność w jego muzyce typowej dla postmodernizmu otwartej estetyki możliwości, potoczności i rozrywki ${ }^{47}$. Przekonanie o równoważności różnych „głosów”, a także o tym, iż „wszystkie tradycje są ważne”, wiąże się natomiast ze współczesnym postrzeganiem świata jako złożonego $\mathrm{z}$ wielu równoważnych perspektyw $^{48}$. Jak pisał Jonathan D. Kramer, „postmodernistyczna muzyka jest aprobująca, a nie wykluczająca; akceptuje różnorodność muzyki w świecie, przyjmuje wiele muzyk" 49 . Zdanie to odzwierciedla poglądy kompozytora, od początku wskazującego w wywiadach na istotę oraz cel swojej III Symfonii. Przenosząc brzmienia wywodzące się z „nieelitarnej” muzyki hip-hopowej w sferę koncertowej muzyki artystycznej, kompozytor zatarł pierwotną funkcję tej pierwszej, jej przeznaczenie i estetyczną genezę. Poza koncepcją łączenia tzw. stylu wysokiego z popularną muzyką masową, typowy dla postmodernizmu pluralizm objawia się także w III Symfonii współegzystowaniem różnych modeli i technik kompozytorskich. Różnorodność ta obejmuje zarówno adaptację elementów współczesnej muzyki popularnej, jak i sięgnięcie po środki muzyczne charakterystyczne dla awangardy oraz późniejszych dwudziestowiecznych nurtów. Niektóre fragmenty utworu, poprzez obecność muzycznych repetycji i towarzyszących im progresji, nawiązują do typowego dla minimalizmu kształtowania materiału. Do stricte postmodernistycznych środków kompozytorskich zaliczyć można także eksponowanie melodyjności oraz wyrazistość rytmu i akcentuacji ${ }^{50}$. Postmodernistyczny pluralizm widoczny jest również w zestawianiu w III Symfonii quasi-tonalnej „muzyki” D, imi-

47 Idee modernizmu i postmodernizmu w poetyce kompozytorskiej i refleksji o muzyce, red. A. Jarzębska, J. Paja-Stach, Kraków 2007, s. 7-14.

48 J. Pasler, Postmodernism, [w:] The New Grove Dictionary of Music and Musicians, red. S. Sadie, t. 20, New York-London 2001, s. 213.

49 J.D. Kramer, O genezie muzyki postmodernizmu, tłum. D. Maciejewicz, „Muzyka” 2000, nr 3; cyt. za: Idee modernizmu..., dz. cyt., s. 43-44.

50 Por. D. Krawczyk, Postmodernizm. Esej o muzyce polskiej, [w:] Kompozytorzy polscy 1918-200o, red. M. Podhajski, t. 1, Eseje, Gdańsk-Warszawa 2005, s. 298. 
tującej brzmienia rapu i trip-hopu, „muzyki” B opartej na ścisłej, dodekafonicznej strukturze oraz „muzyki” E, wykorzystującej brzmienia niemal punktualistyczne. W partii wokalnej typowy dla rapu sposób deklamacji przeplata się natomiast $\mathrm{z}$ fragmentami „romantyzującymi", eksponującymi pierwiastek liryczny, a także z odcinkami o wyraźnie „współczesnym” charakterze. Pod względem harmonicznym w III Symfonii obecne są zarówno tradycyjnie konstruowane, quasi-tonalne akordy, jak i współbrzmienia dysonansowe oraz mikrotonowe.

III Symfonia jako utwór o intertekstualnych kontekstach i odniesieniach - wskazywanych częściowo przez samego kompozytora przynależy do współczesnego muzycznego „dyskursywnego uniwersum kultury" ${ }^{11}$. Bezpośrednie oraz pośrednie odwołania utworu do różnorodnych sfer muzycznej tradycji i współczesności sprawiają, iż rozpatrywać można go pod kątem szeroko pojętego „tekstowego" dialogu, zespolonego jednak z autonomicznym i indywidualnym językiem kompozytora, polegającego na spotkaniu „tego, co nowe, z tym, co dawne [i] tego, co odmienne - z tym, co własne"52. Jak pisze Mieczysław Tomaszewski, podstawą do rozpatrywania utworu w kategoriach intertekstualnych jest obecność w nim wszelkich „wpływów zewnętrznych" ${ }^{3}$. W przypadku III Symfonii wpływy te były dla Mykietyna podstawowym założeniem już przy początku pracy nad utworem. Przywołując poprzez stylizację brzmienia typowe dla współczesnej muzyki popularnej, odniósł część „muzyk” i część pozostałych fragmentów Symfonii do teraźniejszości jako kontekstu. Poprzez zróżnicowanie brzmieniowo-fakturalne pozostałych „muzyk”, konstruowanych na wzór sonoryzmu czy dodekafonii, kompozytor odwołał się z kolei do szeroko pojętej muzycznej tradycji, pełniącej tu funkcję inspiracji ${ }^{54}$. Stylistyczna wielorakość III Symfonii opiera się na sukcesywnym koegzystowaniu w niej wielu typów muzycznej wypowiedzi - zarówno w warstwie orkiestrowej, jak i wokalnej. Historyczne już poniekąd odniesienia „muzyk” kształtujących formę trzech pierwszych części utworu dotyczą zarówno ich warstwy stylistycznej, jak i strukturalnej. „Muzyki” A oraz D - stylizowane na muzykę popularną, stanowiącą

51 R. Nycz, Poetyka intertekstualna. Tradycje i perspektywy, [w:] Krzysztof Penderecki muzyka ery intertekstualnej. Studia i interpretacje, red. E. Siemdaj, M. Tomaszewski, Kraków 2005, s. 7.

52 M. Tomaszewski, O muzyce polskiej..., dz. cyt., s. 15.

53 Tamże.

54 Tamże, s. 16. 
ich rzeczywisty „punkt dojścia” (a więc główny punkt odniesienia) ${ }^{55}$ przenoszą jej stylistyczny idiom na grunt koncertowej muzyki orkiestrowej, niejako likwidując także jej pierwotny kontekst brzmieniowy. Pozostałe „muzyki”, a także niektóre fragmenty Symfonii stanowią reminiscencję historycznych nurtów i stylów, o czym świadczy chociażby romantyzujący liryzm IV części ${ }^{56}$. Przejmując dziedzictwo historycznej tradycji muzycznej w postaci tonalności, dodekafonii czy ukształtowań czysto kolorystycznych, kompozytor w III Symfonii równoważy te środki, podporządkowując je wiodącemu tonowi utworu: „odartemu z patosu" i „dionizyjskiemu" 57 .

Dekonstrukcja jako jeden z głównych nurtów postmodernizmu, określana niekiedy mianem filozofii różni, wiąże się z wielostronnym sposobem postrzegania wieloznacznego dzieła sztuki ${ }^{58}$. Interpretacja III Symfonii w świetle jej założeń wynika z obecności w utworze określonych cech koncepcyjnych i strukturalnych. Dekonstrukcja objawiająca się współobecnością dwóch odmiennych elementów tworzących „układ binarny”, w ramach którego zmianom ulega jego wewnętrzna hierarchizacja - w III Symfonii posiada wymiar podwójny. Odnosi się bowiem do dwóch podstawowych aspektów utworu: koncepcji oraz struktury. Jako kompozycja naśladująca w sposób intertekstualny brzmienia popularnej muzyki młodzieżowej, dekonstruuje zarazem podstawową jej koncepcję - pozostając symfonicznym dziełem o przeznaczeniu koncertowym, przekracza i rozszerza bowiem swoje podstawowe założenia gatunkowe. Owo zdekonstruowanie istniejącego już „obiektu”, oznaczającego w przypadku III Symfonii styl oraz konwencję muzyki hip-hopowej, w ślad za Beatą Fiugajską połączyć można z derridiańskim pojęciem „szczepienia”59.W warstwie struktury, a więc w formalnym rozplanowaniu utworu, zmiana hierarchizacji pomiędzy przeciwstawnymi elementami uwidacznia się w formie (de)gradacji - środka, za pomocą którego zdekonstruowaniu ulega znaczenie odcinków muzycznych jako podstawowych komponentów struktury utworu.

55 Tamże, s. 27.

56 Por. tamże, s. 32.

57 P. Mykietyn, Wywiad o „III Symfonii”..., dz. cyt.

58 Idee modernizmu..., dz. cyt., s. 14.

59 B. Fiugajska, dz. cyt., s. 134, 146, 147. „Strategię szczepienia” autorka utożsamia z szeroko rozumianą strategią cytatu. 
Konstruktywiczny charakter III Symfonii wynika z obecności w niej rygorystycznych założeń, ścisłości i prekompozycyjnych wzorców. Jak wynika z przeprowadzonej analizy utworu, rygory te dotyczą formy, organizacji czasu i organizacji wysokości dźwięków - aspektów dzieła mających w muzyce Mykietyna znaczenie szczególne. Duża rola techniczności, okazująca się istotną, choć jakby „podskórną” cechą utworu, zadecydowała o jego niechaotycznej organizacji. Strukturalne myślenie przejawia się już w redukcyjnym ukształtowaniu cyklu Symfonii, polegającym na skracaniu kolejnych jej części pod względem czasu trwania oraz rozmiarów. W sferze mikroformy środek ten - wiążący się z formą acceleranda - zmienia podstawowe założenia związane z ukształtowaniem formalnym dzieła muzycznego. Drugim ważnym przejawem konstruktywicznego myślenia Mykietyna jest ścisłe operowanie czasem poprzez "permanentne accelerando" - środek stanowiący przykład adaptacji obliczeń matematycznych do sfery dźwiękowej. Ostatni, równie istotny przykład konstruktywizmu III Symfonii, związany ze ścisłym, wręcz strukturalnym traktowaniem materiału dźwiękowego, dotyczy dwunastotonowości zastosowanej w kilku fragmentach utworu. Wprowadzenie w I części rozbudowanej, dodekafonicznej nadserii staje się podstawą dla jej dalszych powrotów i permutacji, ujmowanych w nowe i całkowicie odmienne wersje dźwiękowe.

\section{Zakończenie}

Podejmując próbę spojrzenia na III Symfonię pod kątem jej cech konstytutywnych, w oparciu o przeprowadzoną analizę i interpretację, na plan pierwszy wysunąć można dwa jej aspekty, zasygnalizowane w tytule niniejszego artykułu. Utwór ten jest mianowicie wyraźnym przejawem postawy postmodernistycznej, lecz zarazem naznaczony jest przez ścisłość myślenia kompozytorskiego, stanowiąc przykład muzycznego konstruktywizmu. III Symfonia, podobnie jak niektóre z pozostałych "dojrzałych” utworów kompozytora, odzwierciedla specyficzny sposób realizacji ścisłych założeń prekompozycyjnych. Mykietyn nie kształtuje swoich utworów w całości według jednego i określonego rygoru - stosuje raczej różnorodne, uprzednie wobec zapisanego dzieła reguły w jego wybranych fragmentach. Postawa ta 
potwierdza wielostronność i wieloaspektowość muzyki Mykietyna, stanowiącej w istocie, zgodnie ze słowami Andrzeja Chłopeckiego, rodzaj "postmodernistycznej zabawki”, choć - co potwierdza nieco głębsza analiza III Symfonii - także „zmyślnie wykoncypowanej”60.

\section{Bibliografia ${ }^{61}$}

Chłopecki A., Mykietyna budowanie świata, „Gazeta Wyborcza” 5.07.2008. Cyran K., „Kanon i postmodernizm” w twórczości religijnej kompozytorów polskich przełomu XX i XXI wieku, praca doktorska, Akademia Muzyczna w Krakowie, Kraków 2015.

Cyz T., Uwaga na kulturę!: „III Symfonia” Pawła Mykietyna, „Dwutygodnik" 2011, nr 60, https://www.dwutygodnik.com/artykul/2375-uwaga-na-kulture-o-iii-symfonii-mykietyna.html.

Dahlhaus C., Estetyka muzyki, tłum. Z. Skowron, Warszawa 2007.

Danuser H., Die Musik des 20. Jahrhunderts, Laaber 1984.

Derrida J., Różnia, tłum. J. Skoczylas, [w:] Drogi współczesnej filozofii, red. M.J. Siemek, Warszawa 1978.

Droba K., Górecki Henryk Mikołaj, [w:] Encyklopedia muzyczna PWM. Część biograficzna, red. E. Dziębowska, t. 3 (EFG), Kraków 1987.

Fiugajska B., Technika dekonstrukcji w twórczości Pawła Mykietyna, Kraków 2012.

Herma M., Algorytmy czują bluesa, czyli przepis na przebój idealny, "Gazeta.pl Next" 2.04.2012, http://next.gazeta.pl/next/1,150857,11431816, Algorytmy_czuja_bluesa_czyli_przepis_na_przeboj_idealny.html. Idee modernizmu i postmodernizmu w poetyce kompozytorskiej i refleksji o muzyce, red. M. Jarzębska, J. Paja-Stach, Kraków 2007.

Jabłoński M., Encyklopedia muzyczna PWM. Górecki, Kraków 2011. Krawczyk D., Postmodernizm. Esej o muzyce polskiej, [w:] Kompozytorzy polscy 1918-20oo, red. M. Podhajski, t. 1, Eseje, GdańskWarszawa 2005.

Kwiecińska A., Koncert fortepianowy Pawła Mykietyna w świetle estetyki postmodernistycznej, praca magisterska, Uniwersytet Warszawski, Warszawa 2006.

60 A. Chłopecki, dz. cyt., s. 26.

61 Data ostatniego dostępu do wszystkich źródeł internetowych: 2.12.2018. 
Kwiecińska A., W co gra Paweł Mykietyn?, „Ruch Muzyczny” 2007, nr 10. Majchrowski M., Mykietyna gra z czasem, „Tygodnik Powszechny” 2017, nr 27, https://www.tygodnikpowszechny.pl/mykietyna-gra-z-czasem-148857.

Malecka T., Kwartety smyczkowe Henryka Mikołaja Góreckiego wobec tradycji gatunku, „Teoria muzyki. Studia, interpretacje, dokumentacje" 4 (2014).

Mykietyn P., Komponuję autobiografię, rozmowę przepr. A. Grużewska, „Polityka” 2000, nr 7, https://archiwum.polityka.pl/art/komponuje-autobiografie, 363175 .html.

Mykietyn P., Paweł Mykietyn o swojej najnowszej symfonii [video], rozmowę przepr. M. Peryt, https://www.youtube.com/watch?v=3yiodowM-3I.

Mykietyn P., Paweł Mykietyn. Prezydencja w rytmie trip hopu, rozmowę przepr. F. Łobodziński, „Newsweek” 27.06.2011, https:// www.newsweek.pl/pawel-mykietyn-prezydencja-w-rytmie-trip-hopu/3j8cqtw.

Mykietyn P., Paweł Mykietyn. Wywiad, rozmowę przepr. E. Szczecińska i J. Topolski, „Glissando” 2010, nr 16, http://glissando.pl/tekst/wywiad-pawel-mykietyn-2/.

Mykietyn P., Uwaga na kulturę!: „III Symfonia” Mykietyna, rozmowę przepr. T. Cyz, „Dwutygodnik” 2011, nr 59, https://www.dwutygodnik.com/artykul/2335-uwaga-na-kulture-iii-symfonia-mykietyna.html.

Mykietyn P., Wywiad o „III Symfonii” Pawła Mykietyna [video], rozmowę przepr. K. Naliwajek-Mazurek, „Ninateka”, http://ninateka.pl/ film/wywiad-o-iii-symfonii-pawla-mykietyna-pawel-mykietyn.

Nycz R., Poetyka intertekstualna. Tradycje i perspektywy, [w:] Krzysztof Penderecki - muzyka ery intertekstualnej. Studia i interpretacje, red. E. Siemdaj, M. Tomaszewski, Kraków 2005.

Pasler J., Postmodernism, [w:] The New Grove Dictionary of Music and Musicians, red. S. Sadie, t. 20, New York-London 2001.

Polskie Wydawnictwo Muzyczne, Paweł Mykietyn "Herr Thaddäus” [video], reż. G. Kućmierz, 2018, https://web.facebook.com/PWMEdition/videos/1762997487097976/.

Szwajgier K., Transawangarda, [w:] Książka programowa 58. Międzynarodowego Festiwalu Muzyki Współczesnej „Warszawska Jesień", Warszawa 2015. 
Thomas A., Energia - ruch - życie. Geneza „Elementi”, „Scontri” 2013, nr 1. Tomaszewski M., Na otwarcie: dlaczego „muzyka w muzyce”, [w:] Muzyka w muzyce. Spotkanie muzyczne w Baranowie, red. T. Malecka, L. Polony, Kraków 1980.

Tomaszewski M., O muzyce polskiej w perspektywie intertekstualnej. Studia i szkice, Kraków 2005. 